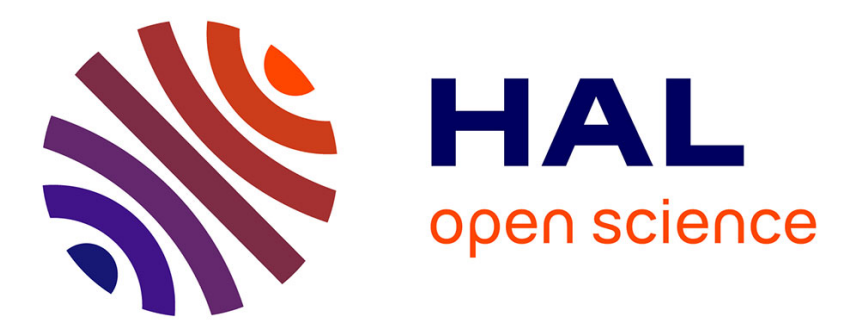

\title{
Discussion on "A Differential Algebraic Estimator for Sensorless Permanent-Magnet Synchronous Machine Drive"
}

Mohamad Koteich, Abdelmalek Maloum, Gilles Duc, Guillaume Sandou

\section{- To cite this version:}

Mohamad Koteich, Abdelmalek Maloum, Gilles Duc, Guillaume Sandou. Discussion on " A Differential Algebraic Estimator for Sensorless Permanent-Magnet Synchronous Machine Drive ". IEEE Transactions on Energy Conversion, 2015, pp.1. 10.1109/TEC.2015.2459791 hal-01183901

\section{HAL Id: hal-01183901 \\ https://hal-centralesupelec.archives-ouvertes.fr/hal-01183901}

Submitted on 12 Aug 2015

HAL is a multi-disciplinary open access archive for the deposit and dissemination of scientific research documents, whether they are published or not. The documents may come from teaching and research institutions in France or abroad, or from public or private research centers.
L'archive ouverte pluridisciplinaire HAL, est destinée au dépôt et à la diffusion de documents scientifiques de niveau recherche, publiés ou non, émanant des établissements d'enseignement et de recherche français ou étrangers, des laboratoires publics ou privés. 


\title{
Discussion on "A Differential Algebraic Estimator for Sensorless Permanent-Magnet Synchronous Machine Drive"
}

\author{
Mohamad Koteich $^{1,2}$, Abdelmalek Maloum ${ }^{1}$, Gilles Duc ${ }^{2}$ and Guillaume Sandou ${ }^{2}$
}

Diao et al. [1] are to be commended for proposing a new approach for permanent magnet synchronous machine (PMSM) position estimation, using the differential algebraic theory. In the following comments, we would like to highlight some points concerning the machine observability under the applied approach.

In the paper by Diao et al. [1], it is claimed that the rotor position observability of the non-salient PMSM is ensured regardless the speed, based on the relationship (8) in [1]. Indeed, (8) is another way to write the back-electromotive force (EMF)-based estimator equation for the non-salient PMSM:

$$
\tan \theta=\frac{-e_{\alpha}}{e_{\beta}}
$$

where $^{1}$ :

$$
\begin{aligned}
& e_{\alpha}=v_{s \alpha}-R_{s} i_{s \alpha}-L_{d} \frac{d i_{s \alpha}}{d t}=-\omega \phi_{m} \sin \theta \\
& e_{\beta}=v_{s \beta}-R_{s} i_{s \beta}-L_{d} \frac{d i_{s \beta}}{d t}=\omega \phi_{m} \cos \theta
\end{aligned}
$$

At standstill, both the rotor position estimate (described by (9) in [1]) and its initial value (described by (10) in [1]) will be indeterminate since their numerator and denominator are null. Physically speaking, if the non-salient (cylindrical) permanent-magnet rotor is fixed with respect to the stator, it will have no effect on the electromagnetic behavior of the stator circuit; the machine model reduces to two spatially static $R L$ circuits without rotational back EMF, and the rotor position cannot be observable using the conventional PMSM model used in [1]. More details on the PMSM observability at standstill are presented in [2] [3].

The fact that the rotor position observability is not ensured at standstill is illustrated in the Fig. 4 of the paper [1], where an initial position estimation error is introduced; the position estimate is not corrected at standstill.

The salient PMSM position estimation expression is not presented in the paper [1]. In contrast to the non-salient PMSM, the rotor position of the salient PMSM can be observable at standstill [2] [3]. Therefore, the study of

Manuscript received March 23, 2015; accepted July 7, 2015.

Mohamad Koteich is with Renault S.A.S. Technocentre, 78288 Guyancourt, France, and also with L2S - CentraleSupélec - CNRS - Paris-Sud University, 91192 Gif-sur-Yvette, France (e-mail: mohamad.koteich@ renault.com).

Abdelmalek Maloum is with Renault S.A.S. Technocentre, 78288 Guyancourt, France (e-mail: abdelmalek.maloum@ renault.com).

Gilles Duc and Guillaume Sandou are with L2S - CentraleSupélec - CNRS - Paris-Sud University, 91192 Gif-sur-Yvette, France (e-mail: gilles.duc@centralesupelec.fr; guillaume.sandou@ centralesupelec.fr).

${ }^{1}$ The same notations as [1] are used. the non-salient PMSM cannot be generalized to the salient PMSM. Nevertheless, the extended back-EMF (E-EMF) concept introduced by Chen et al. [4] [5] can be used to calculate a differential algebraic expression for the salient PMSM. The E-EMF vector can be written as:

$$
\left[\begin{array}{l}
e_{\alpha_{e x t}} \\
e_{\beta_{e x t}}
\end{array}\right]=\left\{\left(L_{d}-L_{q}\right)\left(\omega i_{d}-\frac{d i_{q}}{d t}+\omega \phi_{m}\right\}\left[\begin{array}{c}
-\sin \theta \\
\cos \theta
\end{array}\right]\right.
$$

Then, the rotor position can be estimated using the following differential algebraic relationship:

$$
\tan \theta=-\frac{\dot{y}_{1} L_{d}+R_{s} y_{1}+\omega\left(L_{d}-L_{q}\right) y_{2}-u_{1}}{\dot{y}_{2} L_{d}+R_{s} y_{2}-\omega\left(L_{d}-L_{q}\right) y_{1}-u_{2}}
$$

In this case, the rotor position can be identified at standstill if the first derivative of $i_{q}$ is different from zero.

\section{REFERENCES}

[1] S. Diao, D. Diallo, Z. Makni, C. Marchand, and J. Bisson, "A differential algebraic estimator for sensorless permanent-magnet synchronous machine drive," Energy Conversion, IEEE Transactions on, vol. 30, pp. 82-89, March 2015.

[2] D. Zaltni, M. Ghanes, J. P. Barbot, and M. Abdelkrim, "Synchronous motor observability study and an improved zero-speed position estimation design," in Decision and Control (CDC), 2010 49th IEEE Conference on, pp. 5074-5079, Dec 2010.

[3] P. Vaclavek, P. Blaha, and I. Herman, "Ac drive observability analysis," Industrial Electronics, IEEE Transactions on, vol. 60, pp. 3047-3059, Aug 2013.

[4] Z. Chen, M. Tomita, S. Doki, and S. Okuma, "An extended electromotive force model for sensorless control of interior permanent-magnet synchronous motors," Industrial Electronics, IEEE Transactions on, vol. 50, pp. 288-295, Apr 2003.

[5] A. Akrad, M. Hilairet, and D. Diallo, "Design of a fault-tolerant controller based on observers for a pmsm drive," Industrial Electronics, IEEE Transactions on, vol. 58, pp. 1416-1427, April 2011. 